\title{
In Memory of Jay L. Grosfeld, M.D.
}

\author{
Arnold G. Coran ${ }^{1}$
}

Published online: 18 November 2016

(c) Springer-Verlag Berlin Heidelberg 2016

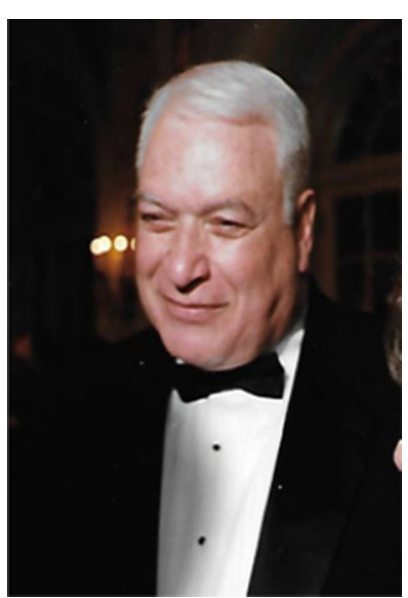

Jay L. Grosfeld, M.D., consummate surgeon, educator, mentor, friend, devoted husband, father and grandfather passed away on October 19, 2016, creating a void in the pediatric surgical world which will be very hard to fill.

Jay was born on May 30, 1935. He did his undergraduate studies at New York University, followed by his medical education at the New York University School of Medicine from which he graduated in 1961. Upon completion of medical school, he entered the General Surgery training program at New York University Medical School/ Bellevue Hospitals, from 1961 to 1966. Directly after completing his training, he was drafted into the United States Army Medical Corps. At the conclusion of his military service, in 1968, he spent 2 years at Columbus

Arnold G. Coran

acoran@med.umich.edu

1 C.S. Mott Children's Hospital, Pediatric Surgery-Room 4-972, 1540 East Hospital Drive, SPC 4211, 48109-4211 Ann Arbor, MI, USA

Children's Hospital as a pediatric surgery resident. At the end of those 2 years, he returned to New York University Medical School as an Assistant Professor of Surgery. At the young age of 37, he was appointed Professor and Director of Pediatric Surgery at Indiana University and the first Surgeon-in-Chief of the Riley Children's Hospital in Indianapolis. Thirteen years later, he was appointed Chairman of the Department of Surgery at Indiana University School of Medicine, becoming the first pediatric surgeon in America to be so honored. In 2003, he retired as the Department Chair leaving a legacy of excellence in clinical, training and research programs.

During his professional life, Jay Grosfeld was recognized as a superb clinician, surgeon, teacher, academician and administrator. His productivity is attested to by his publishing 491 scientific articles in peer-reviewed journals, 135 book chapters and 9 textbooks. He was the Editor-inChief of the prestigious "Pediatric Surgery" textbook and the editor of the same book for several previous editions.

Colleagues around the world recognized his leadership skills by electing him as an officer in major surgical societies such as: Secretary and Chairman of the Surgical Section of the American Academy of Pediatrics, President of the American Pediatric Surgical Association, Chairman of the American Board of Surgery, Vice-President of the American College of Surgeons, President of the World Federation of Associations of Pediatric Surgeons (WOFAPS), to name a few. Jay served as the Editor-inChief of the Journal of Pediatric Surgery, positioning it over these past years as one of the leading journals in the field.

Throughout his career, Jay was the recipient of many prestigious awards, including the Denis Browne Medal from the British Association of Pediatric Surgeons, the William E. Ladd Medal from the American Academy of 
Pediatrics, which is the highest honor bestowed upon a pediatric surgeon in America, the Rehbein Medal from the European Pediatric Surgical Association and Honorary Fellowships in the Royal College of Surgeons Of England, Ireland and Scotland.

In spite of all these many accomplishments, Jay would say that his greatest achievement was his marriage of 54 years to his beloved wife Marge and the wonderful family they produced, their five children, their spouses and seventeen grandchildren. This is his true legacy.
On a personal note, Jay and I first met in 1968 at the annual meeting of the Surgical Section of the American Academy of Pediatrics. We were both chief residents, he was at Columbus Children's Hospital and I was at Boston Children's Hospital. This initial encounter led to a lifelong close personal and professional relationship.

I will miss my friend. We will all miss him. 